\title{
An Analysis of Material Consumption Culture in the
}

\section{Muslim World}

\author{
Aliakbar Jafari, University of Strathclyde, UK
}

Ahmet Süerdem, Istanbul Bilgi University, Turkey

In this paper, we examine the notion of material consumption culture in Islamic societies. We differentiate between institutionalised religion and religion as culture. We contest the Orientalist portrayal of Islam as a fanatic ideology opposed to Western Modernity's features of secularism, individualism, and pluralism. With reference to the Qur'anic text, we discuss that such qualities are embedded with Islam. We do not interpret the Qur'an from a theological perspective; rather, we seek to demonstrate the possibilities of its multiple interpretations. We argue that, in their everyday life consumption practices, Muslims (re)interpret religious guidelines in different ways and refer to Islam, as a transcendental set of guidelines, to make better sense of their cultural practices in different ways. We summarise our discussion by highlighting the importance of analysing the culture of consumption from the lens of insiders and offer directions for future research.

Keywords: Islam, Islamic Societies, Material Consumption, Modernity. Secularity, Sacred, Profane 


\section{Introduction}

Forming almost one fifth of the world population, Islamic societies are significantly absent from the contemporary debates in marketing theory. It would suffice, for example, to say that during 11 years of its publication, Marketing Theory has produced 0 (zero) articles related to marketing phenomena in Islamic societies. This knowledge gap is what we passionately attempt to address in this manuscript. Our key objective is to open up a new scholarly chapter that would both enrich marketing theory and encourage our fellow scholars to proactively take part in this fresh intellectual conversation in order to fill this crucial existing gap. Since the premises of marketing theory are founded on the basic notion of consumption, we endeavour to start our thesis by examining the notion of material consumption culture in Islamic societies. In such contexts consumer culture is "often portrayed as a threat, harmful to religion as it privileges hedonism, pleasure, individualism and an excessive lifestyle" (Wong, 2007, 451). Yet, such a portrayal is superficial and usually reflects a fundamentalist view which demonises material consumption as the realm of irrational excess and disorder, a realm of blasphemy to be abstained. Separation of the sacred and profane is not confined to Islam; institutional religious practices of all creeds have traditionally tried to regulate individuals' consumption activities within the boundaries of religious morale (Varul, 2008). On the other hand, for popular masses, this separation has usually remained artificial in their cultural practices. Sacralisation of mundane objects and activities in order to tame the fear of uncertainty and objectification of sacred ideas into tangible mundane symbols to make better sense of the cosmological order have always been common practices for the popular masses (Eliade, 1959). For instance, popular religious activities such as rituals and feasts are all socio-cultural sites where the boundaries between the sacred and profane are transgressed as cultural sense making activities. 
Within this scope, our major concern in this paper is to illuminate the relationship between Muslims' profane consumption practices and their sacred symbols. Our interest in this topic has been triggered by the observation of a great deal of paradoxes that prevail in Muslims' mundane consumption practices. The nature of consumption practices in Islamic societies, as we perceive it, is complex, dynamic and paradoxical. Take, for example, the following scenarios: a Tehrani young woman - dressed up in a most luxurious fashion and wearing Parisian make-up - who has just arrived home from a party where both men and women were present, changes her clothes, goes to the washroom, takes ablution, spreads her praying mat and stands up to say her evening prayer. In a no less surprising case, after refraining from alcohol during the holy month of Ramadan, Turkish men and women might celebrate the end of their spiritual purgation by drinking $\operatorname{Rakl}^{1}$ and dancing $\mathrm{Halay}^{2}$ at live music concerts. Similarly, after attending their Friday Prayer, Jakartan families might head towards the Senayan City for their weekend hedonic shopping. Maybe none of these would be as astounding as seeing how Arab young male and female students would spend the whole Friday evening talking fervently about the grandeur of Islamic mysticism whilst listening to Ragheb Alama 's ${ }^{3}$ pop music in the background, smoking Sheesha ${ }^{4}$, and drinking Massaya ${ }^{5}$ at the QD's restaurant in Dubai!

There are obvious paradoxes in all these cases. Not only are the 'sacred' and the 'profane' symbiotically present (Belk et al., 1989; Wuthnow, 1994a, 1994b, 1996; Muñiz and Schau, 2005) in these consumption situations, but also the Halal (lawful) and Haram (unlawful), the Mustahabb (favoured) and Makruh (disliked), and the Islamic and un-Islamic are all juxtaposed

\footnotetext{
${ }^{1}$ A non-sweet anise-flavoured spirit popular in Turkey and the Mediterranean

${ }^{2}$ A popular traditional dance in Turkey and the Middle East; other names are Yalli (Iran and Azerbaijan), Dabke or Dabkeh (Arab countries), Dilan (Kurds), Xalai (Greece), and Shourch Bar (Armenia).

${ }^{3}$ Lebanese singer and composer (born 1962 in Beirut)

${ }^{4}$ Also known as Hookah, an instrument for smoking (half-tobacco and half-syrup mixture smoked in a hookah)

${ }^{5}$ Lebanese wine
} 
to shape such mundane consumption practices of these people. Such paradoxes are not exclusively confined to any particular class (e.g., the elites). They exist in different forms at different levels of social classes. Such practices do not only reflect the effects of globalisation of consumer culture; they are grounded in very ordinary cultural habits for the indigenous people of each society. For the unfamiliar observer, these explicit paradoxical combinations of the sacred and the profane and the religious and the un-religious may illustrate either irregularities (e.g., between one's religious beliefs and daily life practices) or transitional stages (e.g., temporary experiential engagement of youth in global consumption culture). Others may view such practices as part of 'consumption creolisation' (Ger and Belk, 1996) in which people enjoy better lifestyles in the presence of global cultural proliferation.

We believe that the paradoxes portrayed in these everyday life practices are significantly overlooked or misrepresented in consumer research debates. Perhaps it is due to the cultural turn's emphasis on identity issues that the culture of consumption in contemporary Muslim societies is predominantly analysed from the lens of Consumer Culture Theory (Arnould and Thompson, 2005). For instance, amongst a host of themes, the existing studies of consumption culture in Islamic societies have examined this subject with reference to the global expansion of consumer culture and multiple discourses associated with globalisation (Ger and Belk, 1996; Pink, 2009; Sandikci and Ger, 2002; Jafari, 2008), issues of resistance or ideological/political identity formation and negotiation (Sandikci and Ger, 2010; Kiliçbay and Binark, 2002; Gökarksel and Secor, 2009; Jafari and Goulding, 2008; Hastings-Black, 2009; Fischer, 2008), and formation of modern identities in new national and international geographies (Wong, 2007; Ger and Østergaard, 1998; Üstüner and Holt, 2007; Khosravi, 2008; Sandikci and Ger, 2010; Jafari and Goulding, 2010). 
Needless to say, we by no means consider replacing rigorous ethnographic research with the above anecdotal evidences. Rather, such evidences significantly violate the clichéd and taken for granted views that Islamic societies are "exceptional" in the sense that they lack or resist consumer culture (Turner, 1994). They do not provide proof but insight for novel research efforts which usually start with the assistance of anecdotal evidences that challenge not only the outsider but insider prejudices. In this vein, the aim of this paper is to question the idea that Islamic creed is "exceptional" and totally stays in the realm of the sacred and excludes mundane consumption practices. For this purpose, we propose a conceptual framework to inform future that would adopt a systematic analysis of such everyday life evidences.

The rest of the paper is dedicated to contest the arguments about Islamic "exceptionalism" on consumer culture and to scrutinise material consumption in order to identify that abovementioned paradoxes are not historical irregularities but inherent in Muslims' cultural practices. Whilst we acknowledge that the expansion of consumption culture in these societies is associated with pervasive globalisation (Kiliçbay and Binark, 2002; Sandikci and Ger, 2010; Pink, 2009; Jafari and Goulding, 2010), we argue, as the core of our debate, that the popularisation of material consumption in the Muslim world is largely stimulated by the embeddedness of this culture within the everyday practices of Islam. In our analysis, we draw on Soroush $(2004,2007)$ and contend that Islam is both secular and plural in nature and it is these characteristics that pave the way for Muslims' multiple interpretations of Islam as a source of constituting multiple lifestyles and consumption practices.

Before further elaboration, two points need to be clarified: 1) by using the term 'Islamic societies', we do not intend to conceptualise Islam as a unified culture. On the contrary, we stress that "like any other religion, Islam has also been historically indigenised in the cultural 
settings of each society" and a large proportion of the cultural habits that societies had traditionally held and lived by before embracing Islam still exist in these communities (Jafari, 2009, 351). Therefore, by 'Islamic societies' we mean those societies where either the majority of the population of a society is Muslim (Jafari, 2009; Pink, 2009) or Islamic rituals are used as a symbol system to make sense of everyday activities (Geertz, 1968). We would also include Muslim diasporas around the world in this population. 2) In this paper we do not intend to interpret the Qur'an from a theological perspective; rather, by referring to the Qur'anic text, we seek to demonstrate the possibilities of its multiple interpretations. We propose that cultural interpretation of symbols in the scripture does not provide a thickly woven web of argumentation about guiding one's life but imply a thin coherence (Sewell, 1999). That is, their decoding provides them with a tool kit to be employed for building different lines of argumentation with the same symbolic resources to lead a good life.

The paper is organised as follows: it starts with a concise review of the current key debates on the theme of the sacred and the profane within the context of market society, with a specific reference to consumption. Next, we summarise Muslim scholars' views on the subject of consumption and religion. Thirdly, we define secularity and argue how it is embedded within the discourse and practice of Islam. Fourthly, we refer to a series of contemporary consumption practices among Muslims to demonstrate the embeddedness of secularity and plurality in Muslims' readings of Islam. Finally, we summarise our discussion by highlighting the importance of analysing the culture of consumption from the lens of insiders and offer directions for future research.

\section{The Sacred and the Profane in Market Society}


The relationship between the sacred and the profane is an established topic for understanding consumption culture in contemporary market societies. Within this scope, Haddorff's (2000) typology of the market-religion interaction is an important contribution in explaining the nature of this relationship. Haddorff identifies three perspectives on the relationship between the sacred and the profane in the market society. First, there is the 'opposition' stream that views religion representing the sacred and the market representing the profane in conflict (Weber, 1958/1904-1905; Marx, 1967/1848). From this standpoint, "the triumph of a market society would lead to the destruction of the fabric of civil society, including the secularisation of religion, and a dystopian collapse of communal solidarity traditional values" (Haddorff 2000, 487). This means that the market operations and practices (including consumption culture) would push religion out of public sphere. At the heart of this market-driven secularisation process, consumption is particularly demonised as a site of modern form of slavery where human beings become prey for the amoral capitalist system (Schor, 1998, 2000). In a market society, people are looked upon mainly from an economic perspective; the more they consume, the better can they help to accelerate the wheels of commodity production in society (Marx, 1967/1848). As a result of this economic rationality, human beings' solid traditional values and authentic and long-term human relationships are replaced by market-generated false values and short-term relationships with objects of consumption (Bauman, 2000). Amongst all these values, religious values particularly diminish as they are replaced by the profane values that are associated with consumption behaviours (Bocock, 1993). For Weber (1993), while rationalisation of human relations represents a historical progress in terms of economic and political organisation, it also leads to the disenchantment of the world by denuding the human existence of its mystical but inwardly genuine plasticity ${ }^{6}$. Yet, Marx observes the decline of

\footnotetext{
${ }^{6}$ Weber argues that as a result of the 'modernisation' process - present in economic rationality and bureaucracy - of an economic system, religion is gradually wiped out of the sphere of public life: "the power of modernization not only causes the institutional life of Western society to fragment into various social and cultural spheres, but it imposes instrumental rationality and bureaucratic structures to govern the practices of these non-market spheres"
} 
religious values as a positive development since he contends that total desacralisation of human relations would instigate the destruction of the capitalist production relations and therefore lead to a quest for the replacement of religious solidarity by secular forms of social solidarity. ${ }^{7}$

The second category is the 'absorption theory' proposed by Emile Durkheim (1984/1893, 1915/1912). This theory, as Haddorff $(2000,490)$ explains, "attempts to reframe the triumph of market society and Homo economicus [economic man] in light of the symbolic boundaries of the 'sacred' and the 'profane'." This theory does not see the sacred and the profane in opposition; rather it holds that there is a symbiotic relationship between the two. For Durkheim religion is not divine; it is a socially constructed phenomenon which, through its 'symbolicexpressive system', assigns meanings to and values for peoples' life goals and behaviours based on the conditions of a given society. Since religion is a socially constructed, and not a transcendental reality, the values it prescribes do not necessarily stand above the culture of society. That is, these values are not assigned by a supernatural source called God; they are defined by the society itself. Therefore, as long as there is balance between the sacred and the profane, the society is healthy and stable. From this perspective, the market based modern

(Haddorff, 2000, 487). Weber's analysis of the erosion of religion from public sphere stresses that religion paradoxically becomes entrapped in the hands of its own creation. That is, "although religious attitudes and beliefs initially shape economic behaviour (e.g. Protestant Ethic), they themselves become trapped in the economic logic of the "iron cage"" (p.487). In Weber's view, the "instrumental rationality of the market" will eventually overcome the "value-oriented rationality" of the religion. As Haddorff further discusses, what is noteworthy in Weber's thesis is the idea of 'disenchantment' which states that the modernisation process of the economic system affects religion in two ways: "First, religious authority and influence over society diminishes because more powerful secular institutions, driven by techno-scientific reason, provide alternative explanations about the meaning and purpose of existence. Second, the attitudes, language, and rational procedures of the secular "public" sphere become so pervasive that they alter the traditional ways of practicing religion" (p.487). For Weber, this secularisation process leads towards a 'dystopian disenchantment'.

${ }^{7}$ According to Marx, in a market-dominated society religion loses its importance and influence. In such a society, “the capitalist 'money economy' dissolves bonds and relations of traditional community by 'masking' the traditional social relations between persons" (Haddorff, 2000, 487). In a capitalist society, social relations are concretised on the basis of mere calculative economic values. Since everything (e.g., the labour involved in different modes of production and commerce) loses its 'use value' and is reduced to 'monetary value', human beings are alienated from themselves, from one another and also from their traditional social and cultural values. "In such a context, religion has no power to transform the market structures themselves, and its impact is limited to caring for persons in light of the harsh realities of the market" (p.487). This secularisation process for Marx leads towards 'a utopian revolution' of the masses. 
economic system is "a historically conditioned way of construing the world, a way of organising and reorganising our core religious beliefs and practices in a secular society" (Haddorff, 2000, 491). This conceptualisation of the 'market as religion' states that the market creates a series of meanings, symbols, values, and life goals that replace the traditional religious values and meanings systems. For instance, through consumption rituals, goods transcend their mere materialistic values and act as symbolic means of creating and negotiating identities and socio-cultural meanings (McCracken, 1988; Frrat and Venkatesh, 1995; Slater, 1997; Boli, 1985). Therefore, through the market system, the profane produces the sacred (Muñiz and Schau, 2005) because "consumers themselves sacralise consumption objects and thereby create transcendental meanings in their lives" (Belk et al., 1989, 32).

The third and final stream of the above mentioned categories is what Haddorff refers to as 'ambiguous tradition' which is epitomised in Polanyi's $(1944,2001)$ thesis of 'double movement'. According to Haddorff, whilst this tradition shares common ground with the first two streams, it differs from them on certain points. Like the oppositional perspective, it believes that the expansion of capitalist market relations does indeed influence society, but unlike it, rejects the idea of total alienation of religion and secularisation of society. While it maintains that there is a symbiotic relationship between the market and religion, like the second view it also sees religion as a transcendental reality. According to Polanyi, society develops decommodification strategies as a self-defense mechanism either through redistribution or reciprocity against the commodification of human relations. Whilst the redistribution occurs within the realm of welfare politics, reciprocity occurs in the realm of the culture. Sacralisation of some activities and objects protects them against pervasive expansion of the commodification of human relations. Hence, as Haddorff further maintains, this argument points to an interaction between religion and the market. That is, on the one hand, the market 
continues to pursue its intended institutional goals (e.g., increasing consumption and production of goods); and, on the other hand, the society continues to sustain its social order and protect its members by employing its available resources (e.g., welfare politics, religion and culture). From Polanyi's perspective, "since the problems of society are inherently social rather than political or economic, it is through a rediscovery of society (or community) that persons begin to engage, resist, and even transform market society" (Haddorff, 2000, 494). In this regard, religion plays a crucial role in supplying the society with the values that endure and respond to people's communal and individual needs in social life. Even in a market society, religion continues to exist and address people's everyday life needs and material consumption does not lead to the deterioration of religious values in society. In Haddorff's words (p.498), like all areas of human activity, "the market is infused with moral values, principles, and virtues, which draws from the 'public' role of religious and ethical discourse." Therefore, neither the market is totally profane, nor is religion totally sacred. For instance, as the analysis of the dominant contemporary consumer culture in the USA reveals, the material consumption rituals in Americans' daily lives do not distance them from their religious beliefs (Wuthnow, 1994a, 1994b, 1996; Marty, 1995; Schmidt, 1995). Material consumption in these societies serves these people to practise transcendental moral and social values such as 'freedom', 'success', and 'well-being':

"The philosophy of hedonistic materialism does not drive the practice of consumption. Rather, consumption is linked with the basic life values of health, security, being loved, beauty, knowledge, relaxation, and social solidarity. Through consumption persons embody these nonmarket 'values' or 'goods', which ironically assists persons in attaining the 'non-material' good life." ～(Haddorff, 2000, 497) 


\section{Consumption culture and Islamic scholarship}

The fact that Islam puts some limits on the consumption of certain goods and services such as alcohol, pork, and gambling is a basic convention in Islamic scholarship. We do not intend to delve into this issue in detail. Suffice to say that Islam advises human beings to maintain health, both of their own and that of society in general. This is a recurrent theme in the Qur'an: "And cast not yourselves to destruction with your own hands" (2:195) or "And slay not the life which God hath forbidden" (17:33). Such statements stress the fact that God has bestowed human beings with health and has shown them good ways of living: "He [the Prophet] commands them what is just, and forbids them what is evil; he allows them as lawful what is good, and prohibits them from what is bad" (7:157). Therefore, mankind is responsible for his own deeds as ways of good life are already made clear to him. When taken as cultural codes, such transcendental guidelines that are reflected in the Holy Book remain open to interpretation within the framework of different cultural contexts. They constitute a loosely structured symbol system that allows for a constant negotiation of sacred doxas, "the experience by which the natural and social world appears as self-evident" (Bourdieu, 1977, 164). Within this frame, social agents remain free to use the implicit practical logic situated in localised bodily dispositions as a benchmark to fill these scripts with meaning. That is, the basic tenets of Islam are open to constant reinterpretation according to localised daily practices in different cultural and social traditions.

Islam also essentially forbids 'waste' (israf) (Kahf, 1992a, 1992b; Hasan, 2005): "Do not squander wastefully. Surely the squanderers are the fellows of the Satan" (17:26-27). A review of the existing literature on consumption from Islamic perspective indicates that the current studies mainly rotate around the notion of Islamic modesty, as 'opposed' to the Western model 
of consumerism (Sandikci and Ger, 2009). A large number of contemporary Muslim writers (e.g., Motahari, 2000; Khan, 1984; Kahf, 1996; Kalantari, 2008; Ormanlar, 1999; Akbari, 1992; Razzaghi, 1996) argue that market-driven modes of consumption contradict the foundations of the Islamic way of life. From this standpoint, Islamic writings share certain similarities with the 'opposition' perspective explained above. It is argued (Kalantari, 2008; Motahari, 2000) that consumerism promotes Western model of individualism and hedonism which threaten the foundations of societal integrity, family values, and the authentic Islamic identity of Muslims. It also presumably paves the way for the capitalist West's economic and cultural invasion of Islamic societies (Razzaghi, 1996; Moidfar, 2000). In this regard, Kiliçbay and Binark $(2002,501)$ maintain that "the capitalist system is powerful enough to assimilate religious institutions, ethics and the aesthetics of Islam into consumption, which is thereby considered a threat to the Islamic lifestyle." In the eyes of these scholars, the culture of consumerism not only transgresses the boundaries of 'modesty and self-sacrifice' (Kahf, 1996), but also dehumanises human beings by depriving them of their true human values such as dignity and spirituality (Motahari, 2000). For instance, in the realm of fashion-oriented lifestyle, the market-legitimised consumerism results in the "surrender of the religion and its practices to the capitalist consumption culture" (Aktaş, 1995 in Kiliçbay and Binark, 2002, 502). Common to these discussions is the equation of the term 'consumerism' with 'overconsumption' of even permissible goods and services. Therefore, the solution offered is modesty. Although we admit that modesty is one of the basic doxas of Islam, we contest the idea that it endows Muslims with a strict way of life; this principle may have different interpretations depending on the culture and the individual. For some, this may mean a conservative value like puritan capital hoarding, while for the others it may mean a progressive value like preserving the ecological and social resources through conservation. 
In this vein, the concept of 'modesty' constitutes a pivotal part of Islamic consumption discourse. This notion has been so important that some scholars (e.g., Kahf, 1996; Kalantari, 2008) argue that the amount of income earned should not have a great impact on Muslims' consumption patterns. The rationale for this is that Islam calls upon human beings to avoid extravagance and organise their lifestyles according to the average economic level of their society so that the poor do not feel inferior. In order to theorise 'modesty', some Muslim writers (see, for example, Khan, 1995; Kalantari, 2008) classify people's needs into three categories of daruriyat or necessities of life like foods, clothing, health care, etc.; hajiyat or complements which would improve the quality of basic needs; and tahsiniyat or the needs whose satisfaction provides people with recognition or social status. It is based on this classification that Muslims are advised to avoid indulgence in the second and third categories because hajiyat and tahsiniyat would entrap human beings in uncontrollable modes of consumerism and would eventually distance them from Islamic values.

For the reasons that follow, we believe that the idea of taking Islamic principles as inflexible dogmas thickly shaping consumption practices is problematic. Firstly, the analysis of consumption culture in Islamic societies suffers from all-encompassing generalisations used as an alternative to rigorous theorisation efforts. Muslim writers generally attempt to define Islamic consumption in contrast with Western modes of consumerism. Hence, they refer to many ambiguous and contested theoretical positions (e.g., cultural invasion and economic exploitation) which themselves need clarification. The notions of consumption culture and consumerism are two different concepts that are the centre of contested debate even in Western societies (see Schor, 1998, 2000; Thompson, 2000; Lamont and Molnar, 1999). Secondly, these Muslim scholars conceptualise the culture of consumption solely from a Colonialist/Imperialist perspective and assume that the culture of consumption in Muslim societies is affected in a 
one-way tradition by the omnipotent Western consumerism. They assume that Muslim societies are blank texts absorbed by the culture of the capitalist West. They also fail to analyse the ever-changing conditions of contemporary life in Muslim societies and ignore the historical trajectories that have traditionally shaped the foundations of private and public lives of Muslims. Finally, they fail to acknowledge the fact that consumption is context-dependent and cannot be equally standardised in all societies. The above classification of needs (daruriyat, hajiyat, and tahsiniya), as Hasan (2005) tactfully notes, does not add much to our understanding of the concept of 'modesty'. The depiction of these principles as hierarchical needs overshadows the non-linear complex nature of needs since it is hard to externally define what is or is not a need for a person. These classifications are ill-defined and problematic; they cannot be applied to peoples' consumption practices. Therefore, the concept of 'modesty' which is used to shed light on the explanation of consumption - becomes another conundrum in itself. Human needs are context-bound; what is regarded as a necessity for one person may complement other basic necessities for another. The best thing to do is, therefore, to leave its definition to localised particular interpretations.

\section{Islam and secularity}

A great deal of sociological misconception picturing Islam as the other of modernity comes from Weber. According to Weber, the main thrust behind the development of modern institutions in Western and especially in Protestant cultures was the internalisation of a valuerational ethics by the individuals. Weber distinguishes between two types of rational actions in terms of their ends orientation: instrumental rationality is merely concerned with short term self interests while value rationality is concerned with the long term realisation of the ultimate meaning of life. Instrumental rational action is oriented towards the indulgence of a multiplicity of mundane ends while the value rational action is oriented towards a single meaningful end. 
The only motivation behind the instrumental rational action is the pursuit of bare self interest while the value-rational action is bounded by self-disciplined codes of conduct. Building on these premises, Weber relates the development of rational capitalism to the emergence of Puritan ethic which allegedly formed the modern individual to internalise the value rationalcodes of conduct. As the secular ascetic Puritan creed required the individual to work for establishing the "kingdom of heaven" in this world, the Puritan individual overcame the duality between the pursuit of pure self interest and striving for higher ends. To justify this thesis, Weber made a cross-cultural comparison of major world civilisations to discern the factors leading to rational modern institutions. Among these civilisations, Weberian construal of Islam is the polar opposite of the Puritan ethic. In Weber's terms, the most valued end according to the Islamic creed is martyrdom in the name of spreading the Islamic deeds ( $\mathrm{Jihad}$ ). This made the warrior class as the main carrier of Islamic values who appropriated this end into a mundane quest for instrumental rationalism. As all the sins would be forgiven in case of martyrdom, warrior individuals found themselves licensed to enjoy the pursuit of short-term self-interests in a guilt free way. In turn, the ruling warrior class has indulged in hedonistic activities especially towards women, luxury and property. On the other side of the coin, the disempowered masses found salvation in a mystical flight to an otherworldly realm. While the conduct of the warriors was motivated by instrumental rational action, the Sufism ${ }^{8}$ served for the emotional relief of the poor masses leaving no place for the value-rational action. Consequently, the separation of the worldly means from the symbolic ends failed to produce the fundamental conditions compatible with the emergence of the modern institutions and mentality.

\footnotetext{
${ }^{8}$ Sufism is a tradition of adherence to the inner mystical dimension of Islam in order to directly establish an encounter with God. Sufis (those who practise Sufism) believe that in order to connect to God, they should wash their hands off the material life and purify their hearts and minds. For further information, please see Subhan, J.A. (1939) Sufism, Its Saints and Shrines. Lucknow: Lucknow Publishing House. \& Lings, M. (1975) What is Sufism? CA. Los Angeles: University of California Press.
} 
These ideas of Weber make part of typical Orientalist (see Said, 1978) view of the Islamic culture and overlook the complex nature of the relation between the religion and everyday practices. As Al-Azmeh $(2003,26)$ elaborates, such an exceptionalist portrayal of Islam as the "trans-historical protoplasm in the life of all Muslims" was widely shared not only by the outsiders but also by the insiders. This portrayal constructs it as a culture which "in itself explains the affairs of Muslim collectivities and over-determines their economies, societies, and non-religious cultures.” In this regard, Soroush (2000) also contests the idea of Islamic exceptionalism and argues that Islamic creed is not intrinsically different than other creeds in its basic values. Separating 'religion per se from religious knowledge' he contends that the elements of secularity, individuality, and plurality are all embedded within the discourse and practice of Islam. In Soroush's view, religion per se is "the essence of religion" and "is perceived as beyond human reach, eternal and divine" and religious knowledge is "a sincere and authentic but finite, limited, and fallible form of human knowledge" (Sadri, 2001, 259). Since religious knowledge is situational and capable of diverse interpretations, there are multiple types of religiosities (Soroush, 2000). That is, the same religion can be interpreted and practised differently by different people around the world. In the rest of the paper, we discuss these characteristics with reference to the Qur'an and examples of consumption practices of Muslims based on different interpretations of Islam.

\section{Secularity and Lifestyle}

Contrary to the common misconception, rejection of monastic asceticism and celebration of life in a secular manner is inherent in Islamic scripture (Jafari, 2010): “God is He Who created the heavens and the earth and caused water to come down from the clouds, and brought forth therewith fruits for your sustenance; and He has subjected to you the ships that they may sail 
through the sea by His command, and the rivers too has He subjected to you" (The Qur'an, 24: 32). Quite contrary to the stereotypical interpretations of Islam as a Spartan ideological regime, the essence of Islam is about how to live an organised, happy, healthy, and prosperous life that would then lead mankind to eternal salvation (Jafari, 2010). After its emergence in 630 AD, with its appealing considerations for the universal human's innate aspirations for good life, Islam helped to improve peoples' daily life conditions (Motahari, 1983). Such a life was not solely the life hereafter (celestial) but a very worldly-lived one (earthly). The abundance of the teachings of the Qur'an on everyday life affairs such as dressing, eating, sexuality, matrimony, hygiene, and the like provides strong evidence for the fact that Islam spoke a familiar language of the temporal (Soroush, 2004). God's earth is the one we are familiar with: "And He has set the earth for His creatures; Therein are all kinds of fruit and palm-trees with sheaths; And grain with its husk and fragrant plants" (55: 10-12). His Heavens are also described in an earthly manner: "There will wait on them youths, who will not age; Carrying goblets and ewers and cups filled out of a flowing spring; No headache will they get therefrom, nor will they be intoxicated; And carrying such fruits as they choose; And flesh of birds as they may desire; And there will be fair maidens with wide, lovely eyes; Like pearls, well preserved" (56: 1824).

As extracted from the text of the Qur'an, this secularity is geared to outlining a balanced 'lifestyle' that would connect the worldly life to the eternal one. Prophet Mohammad, who was ordered by God to tell people that he was not divine but a mortal human being like others (18:110), constantly advised people to both enjoy their worldly life and at the same time secure their salvation for life after death. It is repeatedly narrated that he 'reproached monastic asceticism' (Majlesi, 2000/1601-1698, 207). A large proportion of the teachings of Islam are focused on providing guidance on people's very mundane life affairs because the earthly life 
was viewed as a field in which human beings are given opportunities to decide their own eternal fate by their deeds. Muslims were advised to build their earthly life in such a way as though they would live forever and think about their eternal life in a way as though they would die any moment (Jafari, 2010). In Islam's view, there is a close symbiotic relationship between the sacred and the profane to the extent that abandoning either one to the benefit of the other is reproached. It is narrated that, like his predecessors (the Prophet and other Imams), Imam Sadegh (the $6^{\text {th }}$ Imam of the Shiites) advised Muslims to keep a balance between the worldly life and the life hereafter: "Those who abandon the worldly life for the sake of the eternal life or the eternal life for the sake of the worldly life are not our followers" (Naraghi, 2009/17711829, 246). However, such Islamic teachings that emphasise sustaining a balanced life are not meant to define a narrow and standard lifestyle for Muslims. They acknowledge Muslims' individual routes to salvation and leading a good life.

\section{Individuality and Plurality}

Islam celebrates differences among human beings: "O mankind, We have created you from a male and female, and set you up as nations and tribes so you may know one another" (49:13). It recognises individuality as a basic characteristic of human beings who live in societal spaces (Motahari, 1984; Rahman, 1980). This can be evident from the fact that a majority of Islamic teachings are at an individual level. Significant issues such as daily prayers and Hajj pilgrimage can be performed individually without clerical mediation (Soroush, 2004). The relationship between God and human beings is very personal and close: "And certainly We created man, and We know what is in his mind, and We are nearer to him than the vein of his neck" $(50: 16)$. In Islam's view, in order to connect to God, human beings do not need a mediator as God is omnipresent and omnipotent. No one can come between God and mankind. The intimacy of the God-man relationship is to an extent that even important issues such as marriage in Islam 
do not need to be authorised and legitimised by a member of the clergy (as the representatives of the Divine) as marriage becomes automatically valid based on the consent between the woman and man (Soroush, 2004). Therefore, as Wong (2007) also notes, it is wrong to assume that Islam rejects individualism. Yet, this individualism is not untamed and anti-social; on the contrary, its embeddedness in community defines certain boundaries for practising a kind of individuality that respects that of others (Rahman, 1980). It is also this individuality that facilitates multiple interpretations of Islam.

Islam is intrinsically plural (Soroush, 2000, 2004, 2007). There is only one God in Islam, but the ways of reaching God are as diverse as the number of human beings. This pluralism is further tangible in Shi'ism in which Islam might be interpreted differently by different juries (foqaha). Such interpretations of Islamic teachings, which are meant to shed light onto people's everyday life situations, largely deal with the concept of 'how to live' (i.e., lifestyle). Therefore, since Islam is open to interpretation, the plurality of interpretations gives the individuals a plurality of practising different lifestyles within certain bounds. This plurality is also further intensified by the fact that Islam as a culture has historically developed according to the sociocultural traditions and life conditions of people in different localities. The contemporary communities we know as Islamic societies did not have the same level of development when they embraced Islam; therefore, their experience with and understanding of Islam must have been different. Hence, peoples' 'cultural understanding' of Islam (Eickelman, 2000, Soroush, 2000) plays a crucial role in constituting localised and personalised forms of Islam. In the following section, we refer to a series of contemporary examples of lifestyles and consumption practices to further illuminate our line of argument.

\section{Islam in Everyday Life}


The majority of Muslims are ‘born’ Muslim. They are born into the cultural practices of their societies which are intermingled with religion as just one of the constitutive resources (e.g., traditions, politics, and incoming ideologies) that shape their everyday lives, personal and interpersonal relations, and worldviews. In their everyday life situations, religion becomes part of their culture to an extent that religious practices become mundane cultural norms without necessarily standing out as specifically extraordinary transcendental rituals. These cultural practices are concatenated with history, ethnicity, gender, literature, art and power relations. Therefore, the lifestyles embedded in these cultural settings can also resemble a diversity of such dynamics. For instance, the fact that women's hejab (veiling) is so widely diverse in different Muslim societies is not simply a matter of women's own choice (as part of their religious/cultural practices) or geographical conditions (e.g., weather) of the contexts in which they live but is also related to the ways women have been historically defined, and are therefore expected to behave in certain ways, in those societies (see Mernissi, 1987; Badran, 2008; Nashat and Beck, 2003). Such complex issues can be further understood in a broader context and in relation to other socio-cultural practices.

'Acontextualised' references to religious sources (the Qur' an and Sunnah) do not seek to reach 'truth' (the core of religion); rather they tend to legitimise certain ways of living which may not even hold true or seem logical according to the conditions of the day in which religion is being practised. Therefore, understanding religion, as Soroush (2000) also affirms, needs historical understanding of the ways religious doctrines both developed and were taught by religious authorities. Religious institutions have traditionally tried to map out the boundaries of 'good' and 'evil', but in their everyday life situations masses negotiate these boundaries. They surf the waves of religious principles to find stability in their lives based on their own interpretations of religion. Religion endures because it supplies the life with meaning (Muñiz 
and Schau, 2005). Popular masses find spiritual and psychological solace, love, discipline, societal values and social bonds, identities, and a host of other things. Yet, in an ever-changing world, in order to preserve their faith, masses 'reflexively' justify their traditional religious beliefs in contrast with other socio-cultural norms and circumstances that are in constant process of regeneration (Giddens, 1999). Besides supplying the individual self with meaning, the interpretation and re-interpretation of religious symbols is embedded in power struggles that attempt to shape the social order in a certain way.

Soroush (2000) reminds us that people's orientation in religion is not uniform. Some people commit themselves to religion because they fear God, others do so because they love God, and there are also those who carry the label of religiosity because it gives them a sense of identity. Consequently, their orientation towards consumption practices and lifestyles vary according to their mode of religiosity. Some may follow Molana's ' ‘love-based mysticism’ (Soroush, 2000) whose religiosity brings colourful spirituality, mixed with dance and music, to people's lives. His aestheticisation of Islam produces a religion of aesthetics, love, and universality which emancipates mankind from all types of man-made imaginary boundaries of religiosity, ethnicity, and nationality. He dances to the tunes of cosmic unity and calls upon human beings to join him in his celebration of love:

"What is to be done, O Muslims? for I do not recognise myself. I am neither Christian, nor Jew, nor Gabr, nor Muslim. I am not of the East, nor of the West, nor of the land, nor of the sea; I am not of Nature's mint, nor of the circling' heaven... I am not of Adam, nor of Eve, nor of Eden and Rizwan. My place is the Placeless, my trace is the Traceless ; 'Tis neither body nor soul, for I belong to the soul of the Beloved..."

(Divan-e-Shams)

\footnotetext{
${ }^{9}$ Molana Jalal ad-Din Moḥammad Balkhi, also known as Rumi (1207-1273)
} 
Hence, some Muslim men and women may follow this kind of Islam by playing Daf (a fairly large frame drum with metal bangles) and performing Sama (Sufi dance). Sama becomes a highly transcendental ritual that elevates individuals to the status of harmony with the celestial. Long before Featherstone $(1998,93)$ observed for postmodern societies, "life style as the active stylisation of life in which coherence and unity give way to the playful exploration of transitory experiences and surface aesthetic effects" was a common practice among Islamic mystics. The symbolic wine reflected in the mystic poetry of Molana also becomes a symbolic means of consummating the profane to reach the divine. For instance, some Muslims may paradoxically celebrate religious feasts such as Ramadan Eid with liquor. Likewise, some people may fall in love with Hafez's ${ }^{10}$ Islam which is a revolt against the hypocrisy of religious institutions:

From the church and hypocritical vestments, I take offence. Where is the abode of the Magi, and sweet wine whence?

For dervishes, piety and sensibility make no sense

Where is sermon and hymn, and the violin's music whence.

(Divan-e Hafez)

Such practices are common among those Muslims who pursue their own ways of religiosity. They may no longer feel the need for the traditional religious institutions to exclusively describe and prescribe religious practices for them. This kind of customisation and personalisation of religion is accelerated in contemporary societies. "Mass education and mass communications...profoundly influence how people think about the language of religious and political authority throughout the Muslim world" (Eickelman, 2000, 125). In their daily life activities, individuals feel empowered to define, independent of their religious authorities, their own unique relationships with their God. In their everyday life situations, they may deliberately sacralise the profane in order to actualise their own ideal individual selves. No wonder why

\footnotetext{
${ }^{10}$ Khwaja Shamsu d-Din Moḥammad Hafez-e Shrazi (1315-1390)
} 
they may take Hafez's symbolic adornment of wine ("The face of my Beloved is reflected in my cup; Little you know why with wine, I always myself align.”) into a common cultural practice that liberates them from the influence of traditional religious institutions and empowers them to practise a different form of Islam. This does not, however, mean the loss of faith in religion. On the contrary, it means that individuals are capable of interpreting and practising religion in a variety of ways based on their life goals and experiences. Those who tend to practise their own personalised Islam still leverage the very core of Islam. They seek to find similarities between their own cultural practices and the traditions of an Islam which celebrates life and legitimises God's copious blessings. They avoid the religious dogmas to enjoy the life God has lavished on them. For instance, reposed on the secularity and plurality embedded in Islam (explained above), they may follow Khayyam's ${ }^{11}$ Carpe Diem to fully embrace life and distance themselves from the institutionalised Islamic dogmas:

\section{Khayyam, if drunk, lift up your cheerful voice, Be happy with the darling of your choice; If in the end, the end of things is naught, Imagine you are nothing now. Rejoice!}

(Rubaiyyat: adapted from Arthur Talbot's translation)

In a similar manner, Al-Azmeh (1995), clearly demonstrates how Islamic symbols of paradise negotiate between the sensual pleasures and the divine knowledge. Islamic descriptions of paradise depict it as the lost object of desire and as the greatest source of imagined worldly pleasure. But like the fires of hell, these pleasures play a purgatory role to reach to eternal Truth. Rather than the eternal pleasure with maidens, the devout desire the paradise to consummate worldly pleasures and identify with the divine. This is not an abstract transcendental but a practical "orgiastic" way of reaching the Truth: the only way to know a

\footnotetext{
${ }^{11}$ Omar Khayyam (1048-1131)
} 
situation, object or a person is to break the limits of the self and enter in an ecstatic encounter with it. A permanent sexual intercourse metaphor denotes such an experience because ecstasy is the closest encounter with another person and the ultimate way something that is non-self can be experientially known. In Islamic culture, figures of paradise have been widely used to delineate the idea that the realm of Truth cannot be reached through abstract knowledge but through sensual experiences. The symbols of paradise are frequently used to negotiate the antagonism between the sacred and profane in cultural products such as poems, folktales, rituals, etc.

In contrast, there are also those who follow Al-Ghazali's ${ }^{12}$ 'fear-based' Islam (Soroush, 2000) which emphasises asceticism and repentance. In their everyday lives, these Muslims may strictly monitor their everyday lives to make sure that they avoid worldly hedonism to secure their eternal happiness. They may turn away from the world and its material pleasures. For instance, some may believe that "poverty is better and safer than affluence because the poor have less of an interest in the worldly affairs and to that extent, they will be more inclined to prayer and pious reflection" (Soroush, 2000, 47). Therefore, they 'romanticise' poverty which is in direct opposition with the solid teachings of Islam which encourage people to improve their economic situation and everyday lives (Jafari, 2010). Alternatively, they may take life hard on themselves by adopting, for instance, frugal lifestyles in order to avoid the sense of guilt that may arise as a result of using the bountiful pleasures of life God has allowed them.

All these examples direct us to a final distinction between two kinds of Islam: "Islam of Identity and Islam of truth: in the former Islam is a guise for cultural identity and a response to what is considered the 'crisis of identity'. The latter refers to Islam as a repository of truths that point

\footnotetext{
${ }^{12}$ Abu Hamed Mohammad ibn Mohammad al-Ghazali (1058-1111)
} 
toward the path of worldly and otherworldly salvation" (Soroush, 2000, 23). In either case, religion will be fragmented and there will be multiple Islams. If Islam is dealt with as identity, Muslims will define their religiosity in contrast with two major groups: non-Muslims and Muslims from other sects and geographical contexts. These identity differences and cultural distinctions will manifest themselves in mundane cultural practices including their consumption practices. In the second instance, if Islam is perceived as a 'repository of truths', again individuals will organise their lives to embrace the 'truth' from their own perspective which may differ from others' 'truths'.

\section{Implications and Conclusions}

Our objective in this paper was to demonstrate that the culture of consumption is Islamic societies is not determined by a series of inflexible religious regulations called 'Islam'. In everyday life situations, Islam, as we have argued, comes in different forms and acts as a culture rather than a dogmatic institution. The fact that the analysis of acceleration of consumption culture in Islamic societies is associated with the dominance of Western model of consumerism is a failure of understanding the culture of consumption in Islamic societies. We argued that Islam defines a general framework in which people could practise good life. Although the generalities of this framework are agreed among Muslims around the world, the lifestyles and consumption practices of people in Islamic societies are in constant change based on the ongoing interpretations of Islam.

In the context of Islam, there is no opposition between the sacred and the profane. Islam reproaches asceticism and celebrates life. There is a symbiotic relationship between these two. In contrast to religion as a mere social construction (conceptualised in the 'absorption' perspective), Islam is indeed a transcendental religion that stands above the culture of society. 
As discussed in our paper, our approach is close to Haddorff's 'ambiguous' perspective. However, we contend that people do not remain in an ambiguous status of dangling between the sacred and the profane. In their everyday life situations, they make deliberate 'choices' in their consumption practices and lifestyles. They practise Islam based on their own readings of the religion which is plural in essence. As social agents in everyday life situations, they do not follow a rigid 'rational logic' of religiosity; rather, they pursue a 'practical logic' and act according to their 'feel for the game' of life (Bourdieu, 1977). Hence, we propose the term 'authorised selection' perspective to denote the fact that with reference to religion itself, individuals authorise themselves to selectively interpret Islam and justify their own choices of lifestyle and everyday life practices. We also stress that understanding a variety of consumption practices in contemporary Muslim societies requires that these practices be investigated from the lens of insiders and with reference to the historical dynamics that have changed Muslims' interpretations of Islam.

Now that we have opened up this topic, we would like to humbly invite our fellow scholars researching and working in Islamic societies to conduct empirical research in order to investigate Muslims' mundane consumption practices in the light of the above discussions. We also invite them to bring their own insights into this scholarly debate and help to refine and advance theory where much is needed. Unlike the West - where the investigation of the profane has outweighed that of the 'Sacred' (Iacobucci, 2001), in Islamic contexts, overemphasis on the 'Sacred' has marginalised the profane. Sticking to the repeatedly narrated abstract generalities about the 'Sacred' will not, by any means, help us understand peoples' everyday life practices and consumption choices in an ever-changing world. As Miller (2003) maintains, consumer culture does not render religious beliefs less worthy; rather, it transforms the nature of religion and religious practices. 
Although grounded in consumer research, these premises offer important implications for marketing theory. Nowadays, consciousness towards Islamic marketing is on the increase. Political and business leaders in Islamic countries are keen to redefine the existing marketing theories and practices such as branding and ethics. In the contemporary marketing and consumer research arena, terms such as Islamic brands, Islamic branding, Islamic Marketing, and Islamisation of markets prevail as buzz words; yet, the discussions in this stream are generally limited to addressing Islam as a segmentation criterion (Alserhan, 2010). These studies can be taken further to understand how Muslim consumers of these brands make sense of the symbolic in order to negotiate their everyday life practices. Such research may embed the symbolic meaning of these brands into power struggles, cultural exchanges, and social norms. Further research may also include how branding can be used to change the "negative image of the Islam' in Western countries (O'Shaughnessy and Baines, 2009). As a brand identity building strategy, emphasising the diverse colours of humanistic and cultural aspects of Islam rather than its repressive features can help to wipe out the prejudice that all Muslims are fanatical zealots preoccupied only with the dogmatic religious aspects of life. For this purpose, Islamic branding should avoid selling Islam to Muslims but strive to create an image that would encompass universal values and address human society at large (Temporal, 2009). Another stream of research can study how global symbols and lifestyles are used as a resistance strategy to totalising aspects of fanatical interpretations of Islam (Jafari and Goulding, 2010). Such studies may be interesting to see how global brands and symbols are appropriated into the existing cultural frames in an innovative way. Last, but not least, since development of theory in marketing is a concern for all, by addressing Marketing Theory audiences, in the age of fragmentation of knowledge, we call for inter-cultural conversations between marketing scholars working in Islamic and non-Islamic contexts. For example, whilst the emergence of 
new journals such as Journal of Islamic Marketing may create opportunities for boosting research in Islamic contexts, they may inevitably widen the gap between Islamic and nonIslamic contexts. There is no Journal of Christian Marketing; neither is there any Journal of Jewish Marketing. Similarly, no Journal of Confucian Marketing exists. Therefore, we reemphasise that researchers (Muslim or non-Muslim) investigating different marketing phenomena in Islamic societies should avoid addressing Muslims as their sole target audience. Instead, they should reach out there and communicate their ideas and research findings with those less familiar with Islam and its multiple dynamics. Polarised categorisation of the world into 'the Islamic' and 'the non-Islamic' will not only not help inter-cultural understanding and communication among scholars and practitioners of marketing and other stakeholders in society, but also severely entrap us, as Pieterse (1996) warns us, in the naively well-trodden paths of those who attempted to institutionalise binary oppositions of Islam versus the West, the Occident versus the Orient, modernity versus religion.

\section{References}

Akbari, B. (1992) Eslam va Masraf. Tehran: Moasseseye Motaleat va Tahghighat-e Bazargani. Al-Azmeh, A. (1995) 'Rhetoric for the Senses: A Consideration of Muslim Paradise Narratives', Journal of Arabic Literature 26 (3): 215-31.

Al-Azmeh, A. (2003) 'Postmodern Obscurantism and 'the Muslim Question', Journal for the Study of Religions and Ideologies 2 (5): 21-47.

Alserhan, B.A. (2010) 'Islamic branding: A conceptualization of related terms', Journal of Brand Management 18 (1): 34-49.

Badran, M. (2008) Feminism in Islam: Secular and Religious Convergences. Oxford: Oneworld Press. 
Bauman, Z. (2000) Liquid Modernity. Cambridge: Polity.

Belk, R.W., Wallendorf, M., and Sherry, J.F. (1989) 'The Sacred and the Profane in Consumer Behaviour: Theodicy on the Odyssey', Journal of Consumer Research 16 (1): 1-38.

Bocock, R. (1993) Consumption. London: Routledge.

Boli, J. (1995) 'The Economic Absorption of the Sacred', in R. Wuthnow (ed.) Rethinking Materialism: Perspectives on the Spiritual Dimension of Economic Behavior, Grand Rapids, MI: Eerdmans Publishing Company, pp. 93-115.

Bourdieu, P. (1977/1972). Outline of a Theory of Practice. R. Nice, (Trans.). Cambridge: Cambridge University Press.

Durkheim, E. (1984/1893) The Division of Labor in Society. W. D. Halls (Trans.). New York: Basic Books.

Durkheim, E. (1915/1912) The Elementary Forms of Religious Life. J. W. Swain (Trans.). New York: Free Press.

Eickelman, D.F. (2000) 'Islam and the Language of Modernity', Daedalus 129 (1): 119-36.

Eliade, M. (1959) The Sacred and the Profane: The Nature of Religion. Willard R. Trask (Trans.). New York: Harcourt Inc.

Featherstone, M. (1998) Consumer culture and postmodernism. London: Sage.

Firat, A.F. and Venkatesh, A. (1995) 'Liberatory Postmodernism and the Reenchantment of Consumption', Journal of Consumer Research, 22 (3): 239-67.

Fischer, J. (2008) Proper Islamic Consumption: Shopping among the Malays in Modern Malaysia. Copenhagen: NIAS Press.

Geertz, C. (1968) Islam Observed: Religious Development in Morocco and Indonesia. Chicago: University of Chicago Press.

Ger, G. and Belk, R.W. (1996) 'I'd Like to Buy the World a Coke: Consumptionscapes of a Less Affluent World', Journal of Consumer Policy 19 (3): 271-304. 
Ger, G. and Østergaard, P. (1998) 'Constructing Immigrant Identities in Consumption: Appearance Among the Turko-Danes', Advances in Consumer Research 25: 48-52.

Giddens, A. (1999) Runaway World: How Globalisation Is Reshaping Our Lives. London: Profile.

Gökarıksel, B. and Secor, A. (2009) 'New Transnational Geographies of Islamism, Capitalism, and Subjectivity: The Veiling Fashion Industry in Turkey', in J. Pink (ed.) Muslim Societies in the Age of Mass Consumption: Politics, Culture and Identity between the Local and the Global. Newcastle upon Tyne: Cambridge Scholars Publishing, pp. 23-52.

Haddorff, D. W. (2000) Religion and the Market: Opposition, Absorption, or Ambiguity? Review of Social Economy 58 (4): 483-504.

Hasan, Z. (2005) 'Treatment of Consumption in Islamic Economics: An Appraisal', Islamic Economics 18 (2): 293-46.

Hastings-Black, M. (2009) ‘American-Muslim Identity: Advertising, Mass Media + New’, in J. Pink (Ed.) Muslim Societies in the Age of Mass Consumption: Politics, Culture and Identity between the Local and the Global. Newcastle upon Tyne: Cambridge Scholars Publishing, pp. 303-24.

Iacobucci, D. (2001) Commonalities between research methods for consumer science and biblical scholarship. Marketing Theory 1(1): 109-33.

Jafari, A. (2008) 'The Impact of Cultural Globalisation on the Interrelatedness of Identity Construction and Consumption Practices of Iranian Youth', European Advances in Consumer Research 8 (1): 539-41.

Jafari, A. (2009) 'Misconceptions of Culture in Cross-cultural Business and Management Studies', International Journal of Management Concepts and Philosophy 3 (4): 349-61. 
Jafari, A. (2010) 'A Historical Review of the (Re)Formation of Markets in the Context of Islamic Capitalism (7th -13 th Centuries)', paper presented at the $1^{\text {st }}$ Interdisciplinary Market Studies Workshop, Stockholm School of Economics, June.

Jafari, A. and Goulding, C. (2008) “We Are Not Terrorists!” UK Based Iranians, Consumption, and the 'Torn Self', Consumption, Markets, and Culture 11 (2): 73-93.

Jafari, A. and Goulding, C. (2010) Globalisation Tug-of-War: Consumption as a Site of Conflict, Advances in Consumer Research 38 (1). First published in 2010 (iFirst).

Kahf, M. (1992a) ‘The Theory of Consumption', in S. Tahir, A. Ghazaly, and S.O. Syed Agil (Eds.) Readings in Microeconomics in Islamic Perspective. Malaysia: Longman, pp. 6168.

Kahf, M. (1992b) A Contribution to the Theory of Consumer Behaviour in Islamic Society. In S. Tahir, A. Ghazaly, and S. O. Syed Agil (Eds.) Readings in Microeconomics in Islamic Perspective. Malaysia: Longman, pp. 90-103.

Kahf, M. (1996) The Demand Side or Consumer Behaviour. In Principles of Islamic Economics, Kuala Lampur: International Islamic University Malaysia.

Kalantari, A. (2008) Eslam va Olgooye Masraf. Qom: Boostan.

Khan, M.F. (1984) 'Macro Consumption Function in an Islamic Framework', Journal of Research in Islamic Economics 1 (2): 1-24.

Khan, M.F. (1995) Essays in Islamic Economics. Islamic Foundation UK.

Khosravi, S. (2008) Young and Defiant in Tehran. Philadelphia: University of Pennsylvania Press.

Kiliçbay, B. and Binark, M. (2002) 'Consumer Culture, Islam and the Politics of Lifestyle', European Journal of Communication 17 (4): 495-511.

Lamont, M. and Molnar, V. (1999) 'Too Much Economics', Boston Review 24 (3/4): 18-20.

Majlesi, B. (2000/1601-1698) Baharolanvar Vol. 73. Tehran: Compani. 
Mandaville, P. (2010) 'Transnational Muslim Solidarities and Everyday Life', paper presented at ISA Annual Convention, George Mason University, February.

Marty, M. (1995) 'Materialism and Spirituality in American Religion', in R. Wuthnow (Ed.) Rethinking Materialism: Perspectives on the Spiritual Dimension of Economic Behaviour. Grand Rapids, MI: Eerdmans Publishing Company, pp. 237-253.

Marx, K. and F. Engles (1967/1848) The Communist Manifesto. London: Penguin.

McCracken, G. (1988) Culture \& Consumption: Culture and Consumption: New Approaches to the Symbolic Character of Consumer Goods and Activities. Bloomington: Indiana University Press.

Mernissi, F. (1987) Beyond the Veil: Male-Female Dynamics in Modern Muslim Society. Bloomington: Indiana University Press.

Miller, V.J. (2003) Consuming Religion: Christian Faith and Practice in a Consumer Culture. New York: Continuum.

Moidfar, S. (2000) Jame'eh Shenasi-e Masael Ejtemaei Ma'aser dar Iran. Tehran: Sarzamin-eMa.

Motahari, M. (1983) Khadamat-e Motaghabel-e Eslam va Iran. Tehran: Sadra.

Motahari, M. (1984) Sociology of the Qur'an. Al-Tawhid Islamic Journal 1(3): http://www.alislam.org/al-tawhid/sociology/title.htm

Motahari, M. (2000) Mas'aleye Hejab. Tehran: Sadra.

Muñiz, A.M. and Schau, H.J. (2005) 'Religiosity in the Abandoned Apple Newton Brand Community', Journal of Consumer Research 31 (4): 737-47.

Naraghi, M. A. (2009/1771-1829) Me'rajossaadah. Tehran: Eslamiyeh Publications.

Nashat, G. and Beck, L. (2003) Women in Iran from the Rise of Islam to 1800. University of Illinois Press. 
Ormanlar, C. (1999) 'Giyim Kuşam Modaları', in O. Baydar and D. Ozkan (Eds.) 75. Yılında Değişen Insan: Cumhuriyet Modaları. Istanbul: Tarih Vakfi, pp.42-91.

O’Shaughnessy, N.J., and Baines, P.R. (2009) 'Selling terror: The symbolization and positioning of Jihad', Marketing Theory 9(2): 227-241.

Pieterse, J.N. (1996) A Severe Case of Dichotomic Thinking: Bassam Tibi on Islamic Fundamentalism. Theory, Culture \& Society 13(4): 123-126.

Pink, J. (2009) Muslim Societies in the Age of Mass Consumption: Politics, Culture and Identity between the Local and the Global. Newcastle upon Tyne: Cambridge Scholars Publishing.

Polanyi, K. (2001/1944) The Great Transformation: The Political and Economic Origins of Our Time. Boston, MA: Beacon Press.

Rahman, F. (1980) Major Themes of the Qur'an. Chicago: The University of Chicago Press. Razzaghi, E. (1996) Olgooye Masraf va Tahajom-e Farhangi. Tehran: Chap-Pakhsh.

Sadri, M. (2001) 'Sacral Defense of Secularism: The Political Theologies of Soroush, Shabestari, and Kadivar', International Journal of Politics, Culture and Society 15(2): 25770.

Said, E. (1978) Orientalism. New York: Random House.

Sandikci, O. and Ger, G. (2002) 'In-Between Modernities and Postmodernities: Theorising Turkish Consumptionscape', Advances in Consumer Research 29 (1): 465-70.

Sandikci, O. and Ger, G. (2007) 'Constructing and Representing the Islamic Consumer in Turkey', Fashion Theory 11 (2-3): 189-210.

Sandikci, O. And Ger, G. (2009) 'Islam and Consumption: Beyond Essentialism', Advances in Consumer Research 36 (1): 210-213.

Sandikci, O. and Ger, G. (2010) 'Veiling in Style: How Does a Stigmatised Practice Become Fashionable', Journal of Consumer Research 37 (1): 15-36. 
Schmidt, L.E. (1995) Consumer Rites: The Buying and Selling of American Holidays. Princeton: Princeton University Press.

Schor, J.B. (1998) The overspent American. New York: Basic Books.

Schor, J.B. (2000) 'The New Politics of Consumption', in J.B. Schor and D.B. Holt (Eds.) The Consumer Society Reader, New York: New Press, pp. 446-62.

Slater, D. (1997) Consumer Culture and Modernity. Cambridge: Polity Press.

Soroush, A. (2000) Reason, Freedom, and Democracy in Islam (Ed.) M. Sadri and A. Sadri. Oxford: Oxford University Press.

Soroush, A. (2004) Islam and the Concept of Secularity. Lecture delivered at CUA School of Law, the USA. May 10 2004. Available: http://digitalmedia.cua.edu/events/event dsp.cfm?event=582.

Soroush, A. (2007) Militant Secularism. Available: http://www.drsoroush.com/English/On DrSoroush/E-CMO-2007Militant $\% 20$ Secularism.html.

Sewell, W.H., Jr. (1999) 'The Concept(s) of Culture', in V.E. Bonnell and L. Hunt (Eds.) Beyond the Cultural Turn: New Directions in the Study of Society and Culture, Berkeley: University of California Press. pp. 35-61.

Temporal, P. (2009) Islamic Brands Ready for Takeoff. Advertising and Society Review, 10 (4),

Thompson, C.J. (2000) ‘A new Puritanism?', in J.B. Schor (Ed.) Do Americans shop too much? Boston: Beacon, pp. 69-74.

Turner, B. (1994) Orientalism, Postmodernism and Globalism. London: Routledge.

Üstüner, T. and Holt, D.B. (2007) 'Dominated Consumer Acculturation: The Social Construction of Poor Migrant Women's Consumer Identity Projects in a Turkish Squatter', Journal of Consumer Research 34 (1): 41-56. 
Varul, M.Z. (2008) 'After Heroism: Religion versus Consumerism. Preliminaries for an Investigation of Protestantism and Islam under Consumer Culture', Islam and ChristianMuslim Relations 19 (2): 237-255.

Weber, M. (1958/1904-1905) The Protestant Ethic and the Spirit of Capitalism. T. Parsons (Trans.). New York: Scribner.

Weber, M. (1993) The Sociology of Religion: Max Weber. E. Fischoff(Trans.). Boston: Beacon Press.

Wong, L. (2007) 'Market Cultures, the Middle Classes and Islam: Consuming the Market?', Consumption, Markets and Culture 10 (4): 451-80.

Wuthnow, R. (1994a) 'Religion and Economic Life', in N.J. Smelser and R. Swedberg (Eds.). Handbook of Economic Sociology. Princeton: Princeton University Press, pp. 620-46.

Wuthnow, R. (1994b) God and Mammon in America. New York: The Free Press.

Wuthnow, R. (1994c) Producing the Sacred: An Essay on Public. Champaign: University of Illinois Press.

Wuthnow, R. (1996) Poor Richard's Principle: Recovering the American Dream through the Moral Dimension of Work, Business, and Money. Princeton: Princeton University Press. 